Berichtigung zum Aufsatz

\title{
Formale Charakteristiken der metrischen Modelle in den empirischen Wissenschaften
}

\author{
Von S. SAgOROFF \\ Volumen 11, 1967, Fasc. 3
}

Seite 194

Soll sein:

Erste Spalte, zweite Zeile:

Systemelemente

, , dritte Zeile:

Stufenelements

Letzte Spalte (Physik):

Beispiel Brahe ist mit

Beispiel Newton $\mathrm{zu}$ vertauschen. 